\title{
PENGARUH METODE LATIHAN INTERVAL INTENSIF TERHADAP PENINGKATAN SNATCH PADA ATLET ANGKAT BESI FAMILY BARBELL CLUB MATA AIR PADANG
}

\author{
Ivan Garcia, Hanif Badri \\ Universitas Negeri Padang \\ ivangarcia300100960@gmail.com
}

\begin{abstract}
The problem in this study is the low ability of the snatch force of weightlifting athletes at the Family Barbell Club Mata Air Padang. From the observations of researchers at the Padang Pariaman Porprov where athletes often drop their forces so that they fail to win medals, the purpose of this study is to determine the effect of intensive interval training on increasing snatch force on weightlifting athletes Family Barbell Club in Padang Springs.

This research is a quasi-experimental study, the population in this study amounted to 25 people. The sampling method used was purposive sampling, the sample used by 5 female athletes and 5 male athletes totaling 10 people. The instrument used in this study was the snatch force ability test starting from the initial test (pre-test), then given the implementation of intensive interval training methods, namely squat training and ending with the final test (post-test). Data analysis and testing of research hypotheses Using t-test with a significance level a $=0.05$.

Based on the results of the study provided a significant influence between the ability of the snatch force weightlifting athlete Family Barbell Club Mata Air Padang. The increase in snatch force is female 2 and male 2 with an average of female initial test 32 and female final test 34 while male initial test 54 and final test 56 . Hypothesis testing is female tcount (4.54)> ttable $(2,776)$ and hypothesis test son of titung (3.03)> table $(2,776)$.
\end{abstract}

\section{Keywords: Intensive Interval Method and Snatch Force}

\begin{abstract}
Abstrak
Masalah pada penelitian ini adalah rendahnya kemampuan angkatan snatch atlet angkat besi Family Barbell Club Mata Air Padang. Dari pengamatan peneliti pada Porprov Padang Pariaman dimana atlet sering menjatuhkan angkatannya sehingga gagal dalam merebutkan medali, maka tujuan penelitian ini adalah Untuk mengetahui pengaruh latihan interval intensif terhadap peningkatan angkatan snatch pada atlet angkat besi Family Barbell Club di Mata Air Padang.
\end{abstract}


Penelitian ini merupakan penelitian eksperimen semu, populasi dalam penelitian ini berjumlah 25 orang. Cara pengambilan sampel dengan purposive sampling, sampel yang dipakai atlet putri 5 orang dan putra 5 orang yang berjumlah 10 orang. Instrumen yang digunakan dalam penelitian ini adalah tes kemampuan angkatan snatch dimulai dari tes awal (pre-test), selanjutnya diberikan pelakuan metode latihan interval intensif yaitu latihan squat dan di akhiri dengan tes akhir (post-test). Analisis data dan pengujian hipotesis penelitian Menggunakan uji-t dengan taraf signifikansi $\alpha=0,05$

Berdasarkan hasil penelitian memberikan pengaruh yang signifikan antara kemampuan angkatan snatch atlet angkat besi Family Barbell Club Mata Air Padang. Peningkatan angkatan snatch adalah putri 2 dan putra 2 dengan rata-rata tes awal putri 32 dan tes akhir putri 34 sedangkan putra tes awal 54 dan tes akhir 56 . Uji hipotesis yaitu putri $t_{\text {hitung }}(4,54)>t_{\text {tabel }}(2,776)$ dan uji hipotesis putra $t_{\text {hitung }}(3,03)>t_{\text {tabel }}$ $(2,776)$.

Kata Kunci: Metode Interval Intensif dan Angkatan Snatch

\section{PENDAHULUAN}

Prestasi olahraga yang telah diukir para atlet Indonesia di kancah internasional telah mengangkat harkat dan martabat Bangsa Indonesia di mata dunia sehingga membangkitkan rasa bangga yang sebesarbesarnya dalam diri setiap Bangsa Indonesia. Dalam UU RI NO 3 Tahun 2005 pasal 27 ayat 4 Tentang Sistem Keolahragaan Nasional dinyatakan bahwa:"Pembinaan dan pengembangan olahraga prestasi dilaksanakan dengan memberdayakan perkumpulan olahraga, menumbuh kembangkan serta pembinaan olahraga yang bersifat nasional dan daerah, dan menyelenggarakan kompetisi secara berjenjang dan berkelanjutan".

Berdasarkan pasal di atas, diketahui cara pembinaan olahraga salah satunya dapat dilakukan dengan menyelenggarakan kompetisi secara berkelanjutan. Olahraga semakin menjadi kebutuhan bagi semua kalangan masyarakat. Hal ini terlihat pada maraknya olahraga yang dilakukan mulai dari lari pagi sampai dengan kebutuhan prestasi, yaitu mulai olahraga permainan yaitu basket, sepakbola, bola voli, maupun olahraga individu, untuk melatih kebugaran yaitu angkat beban, pada 
umumnya latihan beban sering disebut fitness. Dalam olahraga angkat beban, terdapat tiga macam olahraga yang tidak hanya untuk olahraga kebugaran saja, namun juga dipertandingkan ditingkat Daerah, Nasional, maupun Internasional, yaitu Angkat besi, Angkat berat dan Binaraga.

Menurut Edwarsyah (2013:6) Angkat besi merupakan cabang olahraga yang bersaing untuk mengangkat beban berat yang disebut dengan barbel, yang dilakukan dengan kombinasi dari kekuatan, fleksibilitas, konsentrasi, kemampuan, disiplin (sangat penting), atletis, fitnes, teknik, mental dan kekuatan fisik. Kata "angkat besi" biasanya secara tidak resmi digunakan sebagai latihan beban. Angkat besi merupakan olahraga yang dimainkan dengan power yang besar dan kecepatan teknik untuk mengendalikan beban. Olahraga ini memiliki risiko cidera yang sangat besar apabila dilakukan tidak serius. Oleh karena itu dalam setiap berlatih maupun bertanding harus menggunakan tempat, peralatan, dan perlengkapan yang khusus untuk memberi pelindung tubuh untuk meminimalisir terjadinya cedera.

Menurut Mujiatun ( $2008: 17,21$ ) dalam olahraga angkat besi terdapat dua macam teknik angkatan yaitu jenis angkatan Snatch dan Clean and jerk. Jenis angkatan Snatch adalah gerakan mengangkat barbel ke atas secara langsung kemudian baru berdiri dalam keadaan tangan lurus sambil mengangkat barbel. Caranya adalah dua tangan memegang batang barbel (stang), selebar antara 80 s.d $100 \mathrm{~cm}$, kemudian barbell ditarik keatas kepala dalam satu gerakan yang tidak terputus-putus (langsung) dengan posisi tangan menyangga barbel dalam keadaan lurus. Jenis angkatan Clean and Jerk, atlet mengangkat barbel dalam dua tahap, pertama mengangkat beban dari lantai sampai batas dada dengan posisi jongkok.

Setelah jeda sebentar untuk mengambil ancang-ancang, atlet kemudian mengangkat barbel sampai kedua tangan lurus di atas kepala, dengan posisi berdiri sempurna beberapa detik, sampai wasit 
membunyikan bel tanda angkatan sah. Kedua jenis angkatan ini bisa dilombakan satu per satu, namun juga bisa digabung sehingga rekor atlet adalah penjumlahan beban maksimal dari total angkatan Snatch dan Clean and Jerk.

Metode latihan daya ledak menurut Suharno dalam Bafirman dan Agus (2008 : 81) dapat dilakukan dengan beberapa metode latihan antara lain: latihan sirkuit, latihan beban, latihan interval dan sebagainya.Menurut Syafruddin (2011 : 109) "metode interval berdasarkan prinsip interval, yaitu adanya waktu antara (interval pemulihan) di antara pembebanan yang berikutnya. Metode interval ini selain digunakan dalam latihan kekuatan dan latihan kecepatan, juga dapat digunakan untuk pengembangan jenis daya tahan lainnya".

Dalam olahraga angkat besi ada dua jenis angkatan yang dipertandingkan yaitu:

\section{a. Angkatan Snatch}

Yaitu cara memainkannya dengan mengangkat beban dari lantai tanpa boleh menekuk lutut sampai kedua tangan mengangkat beban (barbel) lurus keatas kepala dengan posisi berdiri sempurna beberapa detik, sampai juri membunyikan bel tanda angkatan sah.

b. Angkatan CleanandJerk

Yaitu atlet mengangkat barbel dalam dua tahap. Pertama, mengangkat beban dari lantai sampai batas dada dengan posisi jongkok, setelah jeda sebentar untuk mengambil ancang-ancang, atlet kemudian mengangkat barbel sampai kedua tangan lurus ke atas kepala, dengan posisi berdiri sempurna beberapa detik, sampai juru membunyikan bel tanda angkatan sah.

\section{Latihan Squat}

Menurut Agus (2012 : 95) Squat yaitu beban disimpan diatas pundak. Selanjutnya, kedua lutut ditekukan dan kemudian diluruskan kembali.Menurut Kardiawan (2014 : 109) squat merupakan latihan yang 
sangat baik, kalau tidak dikatakan yang terbaik untuk latihan otot paha. Dapat dilakukan dengan dua macam yakni dengan smith machine atau dengan beban bebas (free weight). Smith machine sangat membantu menyeimbangkan beban dan baik juga bagi pemula sehingga dapat berkontraksi pada otot yang dilatih. Posisi telapak kaki sebaiknya lebih lebar dari bahu. Tekuk lutut dan turunkan badan sampai sejajar atau lebih rendah dari garis paralel dengan lantai. Kembali ke posisi semula.

\section{Daya Ledak}

Menurut Agus (2012 : 79) Daya ledak merupakan salah satu dari komponen biomotorik yang penting dalam kegiatan olahraga. Sedangkan Menurut Corbin dalam Agus (2012: 80) daya ledak adalah kemampuan untuk menampilkan atau mengeluarkan kekuatan secara ekplosif atau dengan cepat. Dari penjelasan diatas dapat disimpulkan, daya ledak adalah merupakan salah satu aspek dari kondisi fisik.Daya ledak sangat berkaitan dengan daya (power).

1) Metode Latihan Interval

Metode interval intensif, metode ini khususnya untuk mengembangkan kekuatan otot ledak (eksplosive strength) dan kekuatan kecepatan.Menurut Arsil (2009 : 56) latihan interval intensif adalah:Metode latihan ini adalah khusus untuk mengembangkan kekuatan ledak (Eksplosive Strenght) dan kekuatan kecepatan (Velocity Strenght). Perlu diingat volume beban latihan berbanding terbalik dengan intensitas beban latihan. Memperberat beban latihan dapat di tempuh dengan jalan hanya memperbesar volume, meningkatkan intensitas, memperpendek waktu recovery, menambah frekuensi dan tempo tinggi dapat pula memperberat beban latihan atau sebagian.

\section{METODOLOGI}

Penelitian ini menggunakan metode penelitian eksprerimen semu. Tujuan adalah "untuk menentukan ada tidaknya perlakuan antara sebab 
dan akibat yang sifatnya membandingkan antara dua variabel yang dikontrol" Arikunto (2010 : 207).

Variabel penelitian ini terdiri dari latihan squat dengan metode interval intensif sebagai variabel bebasnya $(x)$ dan angkatan snatch sebagai variabel terikat (y). Tujuannya adalah untuk menentukan ada tidaknya pengaruh perlakuan sebagai variabel bebas terhadap variabel terikat.

1. Waktu

Penelitian dilaksanakan selama satu bulan, dengan frekuensi latihan empat kali seminggu. Sebelum memulai latihan, terlebih dahulu diambil data awal, Dikasih perlakuan selanjutnya diambil kembali data akhir setelah dilakukan latihan selama satu bulan pada pertemuan terakhir.

2. Tempat Penelitian

Tempat penelitian dilakukan di Sasana Family Barbell Club di Mata Air Padang.

3. Sampel

Berpedoman pada populasi diatas maka sampel yang akan diteliti atlet angkat besi Family Barbell Club yang berjumlah 10 orang, terdiri 5 orang pria dan 5 orang putri di karenakan keterbatasan alat dan tempat saat melakukan penelitian tersebut.

\section{HASIL PENELITIAN DAN PEMBAHASAN}

\section{Hasil Penelitian}

Berdasarkan penjelasan serta uraian yang telah dikumpulkan sebelumnya, maka dalam bab ini akan dilakukan analisis dan pembahasan yang diperoleh dalam penelitian ini. Hasil penelitian ini akan digambarkan sesuai dengan tujuan hipotesis yang diajukan sebelumnya. Data penelitian ini berupa data angkatan snatch. Data yang diambil sebelum perlakuan disebut dengan tes awal (pre-test). Dan data yang diambil sesudah perlakuan disebut tes akhir post-test). Data yang 
diperoleh dari 10 orang sampel yaitu 5 orang putri dan 5 orang putra dikarenakan yang diambil rajin mengikuti latihan, yang telah mengikuti pertandingan dan yang telah lebih latihan dari 5 bulan. Data inilah yang akan di olah.

\section{Data awal (Pre-Test) putri}

Distribusi frekuensi data hasil tes awal putri (Pre Test) angkatan snatch atlet angkat besi Family Berbell Club Di Mata Air Padang.

\begin{tabular}{|c|c|c|c|}
\hline No & Skor & Frekuensi Absolute & Frekuensi Relatif \\
\hline 1 & $25-29$ & 2 & $40 \%$ \\
\hline 2 & $30-34$ & 2 & $40 \%$ \\
\hline 3 & $35-39$ & 0 & $0 \%$ \\
\hline 4 & $40-44$ & 1 & $20 \%$ \\
\hline \multicolumn{2}{|c|}{ Total } & $\mathbf{5}$ & $\mathbf{1 0 0} \%$ \\
\hline
\end{tabular}

Berdasarkan tabel distribusi frekuensi diatas maka dapat dijelaskan dari 5 orang sampel, 2 orang (40\%) memiliki angkatan snatch berkisar $25-29 \mathrm{~kg}, 2$ orang (40\%) memiliki angkatan snatch berkisar 30 - $34 \mathrm{~kg}, 0$ orang (0\%) memiliki angkatan snatch berkisar 35 - 39 kali, 1 orang (20\%) memiliki angkatan snatch berkisar $40-44 \mathrm{~kg}$.

\section{Data awal putra}

Distribusi frekuensi data hasil tes awal putra (Pre Test) angkatan snatch atlet angkat besi Family Berbell Club Mata Air Padang.

Berdasarkan tabel distribusi frekuensi diatas maka dapat

\begin{tabular}{|c|c|c|c|}
\hline $\begin{array}{c}\mathbf{N} \\
\mathbf{0}\end{array}$ & Skor & $\begin{array}{c}\text { Frekuensi } \\
\text { Absolute }\end{array}$ & Frekuensi Relatif \\
\hline 1 & $40-49$ & 2 & $40 \%$ \\
\hline 2 & $50-59$ & 2 & $40 \%$ \\
\hline 3 & $60-69$ & 0 & $0 \%$ \\
\hline 4 & $70-79$ & 1 & $\mathbf{2 0} \%$ \\
\hline \multicolumn{2}{|c|}{ Total } \\
\multicolumn{2}{|c|}{ dijelaskan dari 5 orang sampel, 2 orang (40\%) memiliki angkatan }
\end{tabular}

snatch berkisar $40-49 \mathrm{~kg}, 2$ orang (40\%) memiliki angkatan snatch 
berkisar $50-59 \mathrm{~kg}, 0$ orang $(0 \%)$ memiliki angkatan snatch berkisar $60-69 \mathrm{~kg}, 1$ orang (20\%) memiliki angkatan snatch berkisar $70-79 \mathrm{~kg}$.

Data akhir putri (Post-Test) kekuatan angkatan snatch

Distribusi frekuensi data hasil tes akhir putri (Post-Test) angkatan snatch atlet angkat besi Family Berbell Club Mata Air Padang.

\begin{tabular}{|c|c|c|c|}
\hline No & Skor & Frekuensi Absolute & Frekuensi Relatif \\
\hline 1 & $28-32$ & 2 & $40 \%$ \\
\hline 2 & $33-37$ & 2 & $40 \%$ \\
\hline 3 & $38-42$ & 1 & $20 \%$ \\
\hline \multicolumn{2}{|c|}{ total } & $\mathbf{5}$ & $\mathbf{1 0 0 \%}$ \\
\hline
\end{tabular}

Berdasarkan tabel distribusi frekuensi diatas maka dapat dijelaskan dari 5 orang sampel, 1 orang (20\%) memiliki angkatan snatch berkisar $38-42 \mathrm{~kg}, 2$ orang (40\%) memiliki angkatan snatch berkisar $33-37 \mathrm{~kg}, 2$ orang (40\%) memiliki angkatan snatch berkisar 38 - $42 \mathrm{~kg}$.

Data akhir putra

Distribusi frekuensi data hasil tes akhir putra (Post-Test) angkatan snatch atlet angkat besi Family Berbell Club Mata Air Padang.

\begin{tabular}{|l|l|c|c|}
\hline No & Skor & Frekuensi Absolute & Frekuensi Relatif \\
\hline 1 & $42-51$ & 2 & $40 \%$ \\
\hline 2 & $52-61$ & 2 & $40 \%$ \\
\hline 3 & $62-71$ & 0 & $0 \%$ \\
\hline 4 & $72-81$ & 1 & $20 \%$ \\
\hline \multicolumn{2}{|c|}{ total } & 5 & $\mathbf{1 0 0} \%$ \\
\hline
\end{tabular}

Berdasarkan tabel distribusi frekuensi diatas maka dapat dijelaskan dari 5 orang sampel, 2 orang (40\%) memiliki angkatan snatch berkisar $42-51 \mathrm{~kg}, 2$ orang (40\%) memiliki angkatan snatch berkisar $52-61 \mathrm{~kg}, 0$ orang (0\%) memiliki angkatan snatch berkisar 
$62-71 \mathrm{~kg}, 1$ orang (20\%) memiliki angkatan snatch berkisar $72-81$ $\mathrm{kg}$.

\section{Pembahasan}

Pembahasan dalam penelitian ini dilakukan berdasarkan dari kajian terori dan perhitungan statistik serta mengacu pada kesimpulan terhadap analisis yang telah dilakukan, maka selanjutnya akan dilakukan pembahasan. Berdasarkan hasil analisis yang diperoleh dalam penelitian ini didapatkan hasil Peningkatan angkatan snatch adalah putri 2 dan putra 2 dengan rata-rata tes awal putri 32 dan tes akhir putri 34 sedangkan putra tes awal 54 dan tes akhir 56 dari analisis uji hipotesis putri $t_{\text {hitung }}(4,54)>t_{\text {tabel }}(2,776)$ dan uji hipotesis putra $t_{\text {hitung }}(3,03)>$ $t_{\text {tabel }}(2,776)$ pada taraf signifikan $\alpha=0,05$ pada jumlah sampel 10 orang, 5 putri dan 5 putra.

Jadi dapat disimpulkan Terdapat pengaruh yang signifikan pemberian metode latihan interval intensif terhadap peningkatan angkatan snatch atlet angkat besi Family Barbell Club Mata Air Padang. Secara nyata terlihat adanya peningkatan dari tes awal (pre-test) sebelum diberi metode latihan interval intensif selama 16 kali pertemuan, dengan tes akhir (post-test) setelah diberikan metode latihan interval intensif.

Keterbatasan dalam pelaksanaan perlakuan dalam penelitian ini, walaupun sudah dicoba untuk mengatasi kemungkinan gangguan terhadap variabel penelitian, tetapi pada kenyataannya sulit untuk menghindari munculnya permasalahan selama penelitian dilakukan antara lain: Sampel ada yang tidak hadir ketika jadwal latihan dan peralatan yang kurang memadai. Melakukan kontrol secara ketat terhadap sampel, karena sampel mempunyai kesibukan masing-masing seperti kuliah dan bekerja. Perbedaaan hari saat pengambilan data dikarenakan testee berhalangan hadir saat jadwal tes dilakukan. 
Dalam proses pelaksanan perlakuan, masih ada yang kurang serius, tetapi peneliti berusaha memberi motivasi secara maksimal agar bisa melakukan dengan baik. Peneliti juga tidak bisa mengontrol aktifitas di luar dan gizi testee. Selanjutnya sarana dan prasarana juga menentukan keberhasilan dalam pencapaian hasil latihan yang baik. Sarana dan prasarana yang memadai, baik secara kualitas dan kuantitas, untuk menambah motivasi testee dalam melaksanakan latihan untuk mencapai hasil latihan yang maksimal.

\section{KESIMPULAN}

Berdasarkan hasil dan pembahasan, peningkatan angkatan snatch adalah putri 2 dan putra 2 dengan rata-rata tes awal putri 32 dan tes akhir putri 34 sedangkan putra tes awal 54 dan tes akhir 56 terlihat bahwa nilai putri $t_{\text {hitung }}(4,54)>t_{\text {tabel }}(2,776)$ dan uji hipotesis putra $t_{\text {hitung }}$ $(3,03)>t_{\text {tabel }}(2,776)$ pada taraf signifikan $\alpha=0,05$ pada jumlah sampel 10 orang terdiri dari 5 putri dan 5 putra. Hal ini menunjukan bahwa terdapat pengaruh secara signifikan akibat latihan interval intensif terhadap peningkatan angkatan snatch atlet angkat besi family barbell club mata air padang. Artinya program latihan interval intensif dapat meningkatkan angkatan snatch atlet angkat besi family barbell club mata air padang.

\section{SARAN}

Berdasarkan pada kesimpulan diatas, maka penulis dapat memberikan saran yang dapat membantu mengatasi masalah yang ditemui dalam meningkatkan kemampuan angkatan Snatch, diantaranya:

1. Para pelatih disarankan untuk menerapkan bentuk latihan Squat dalam menjalankan program latihan, disamping faktor-faktor lain yang ikut menunjang peningkatan daya ledak otot paha pada kemampuan angkatan Snatch dalam olahraga angkat besi.

2. Para atlet angkat besi agar memperhatikan latihan Squat untuk dapat meningkatkan kemampuan angkatan Snatch tersebut didalam latihan ataupun pertandingan Olahraga angkat besi. 
3. Bagi para peneliti disarankan untuk dapat mengkaji bentuk-bentuk latihan lain yang berhubungan dengan daya ledak otot paha dalam olahraga angkat besi.

\section{DAFTAR RUJUKAN}

Adnan, Aryadie. 2015. Silabus dan Handout Mata Kuliah Statistik 2. Padang: Universitas Negeri Padang

Arikunto, Suharsimi. 2010. Prosedur Penelitian. Jakarta: RINEKA CIPTA.

Agus Apri. 2012. Olahraga Kebugaran Jasmani. Padang: SUKABINA PRESS.

Agus Apri. (2013). Manajemen Kebugaran Teori dan Praktek.Padang: Sukabina Press.

Agus Apri, Bafirman. 2008. Pembentukan Kondisi Fisik. Malang: WINEKA MEDIA.

Arsil. 2009. Pembinaan Kondisi Fisik. Padang: FIK UNP

Edwarsyah. 2013. Teori dan Praktek Belajar Angkat Besi. Padang : FIK UNP.

Irawadi, Hendri. 2011. Kondisi Fisik dan Pengukurannya. Padang : FIK UNP

Insyani, Sayidati. 2015. HUBUNGAN POWER TUNGKAI DAN POWER LENGAN DENGAN KEMAMPUAN CLEAN AND JERK ATLET ANGKAT BESI PUTRI DI KABUPATEN SLEMAN TAHUN 2015 : Universitas Negri Yogyakarta

Suwirman. 2004. Penelitian Dasar. Padang : Universitas Negeri Padang

Kardiawan, Kasuma. 2014. Pembentukan dan Pembinaan Kondisi Fisik. Yogyakarta: GRAHA ILMU.

Mujiatun. 2008. Olahraga Angkat Besi. Semarang : ANEKA ILMU.

Sajoto Mochamad. 1988. Pembinaan Kondisi Fisik Dalam Olahraga. Jakarta: IKIP PADANG.

Syafrudin. 2011. IImu kepelatihan Olahraga. Padang : UNP Press

Undang-undang Republik Indonesia Nomor 3 tahun 2005 Tentang Sistem Keolahragaan Nasional. JAKARTA. 